\title{
Analisis Resiko Penangkar Benih Padi Pada Program Desa Mandiri Benih Di Kabupaten Pringsewu
}

\author{
Risk Analysis of Paddy Seeds Farming In Seed Self-sufficient Village Program \\ In Pringsewu District
}

\author{
Dyah Rianita Susanti*1, Sudarma Widjaja ${ }^{2}$, Zainal Abidin ${ }^{3}$ \\ ${ }^{1,2,3}$ Magister Agribisnis Universitas Lampung \\ e-mail: *1 dyahrianita1212@yahoo.com
}

\begin{abstract}
The objective of this research was to analyze the risk of rice seed breeder in Pringsewu District. The research was conducted in Pringsewu District. The location was determined purposively, considering that Pringsewu Regency was a rice producing center in Lampung Province. Based on the calculation, the study sample consisted of 37 rice breeders and 37 non-breeders. The data collection of this research was conducted in November 2017. This research employed variation coefficient method to analyze risk. The coefficient of variation $(C V)$ is a measure of the relative risk obtained by dividing the standard deviation by the expected value. The results of the research showed that the level of risk of rice farming in Pringsewu regency for non-paddy breeder farmers was higher than paddy farmer breeders.
\end{abstract}

Keywords: Rice, Risk, Seed

\section{Pendahuluan}

Menurut BPS Provinsi Lampung (2016), produktivitas tanaman padi sawah di Kabupaten Pringsewu sebesar 59,69 ku/ha, lebih rendah jika dibandingkan dengan produktivitas tanaman padi di Kota Metro sebesar 61,80 ku/ha. Hal ini mengindikasikan masih adanya masalah dalam kegiatan budidaya tanaman padi di Kabupaten Pringsewu. Menurut Kurniati (2012), masalah produksi berkenaan dengan sifat usahatani yang selalu tergantung pada alam didukung faktor risiko yang menyebabkan tingginya peluang-peluang untuk terjadinya kegagalan produksi, sehingga berakumulasi pada risiko rendahnya pendapatan yang diterima petani.

Alasan terbesar penggunaan benih produksi sendiri atau benih turunan karena mutunya dianggap lebih bagus dibandingkan membeli di pasaran. Sebagian besar petani melakukan roguing 1 kali selama pertanaman, sedangkan sebagian kecil roguing 2 kali selama pertanaman. Selain itu, petani tidak melakukan pembersihan benih sebelum disimpan. Bila dibandingkan dengan persyaratan mutu benih sebar, sebagian besar benih yang dihasilkan tidak memenuhi persyaratan mutu benih sebar. Benih-benih yang tidak memenuhi syarat tersebut disebakan oleh persentase kadar air atau kotoran benih yang tinggi.

Pengembangan dan pembinaan kelompok tani sebagai penangkar atau produsen benih juga dimaksudkan untuk meningkatkan nilai tambah hasil pertanian mereka yang tujuan akhirnya adalah untuk meningkatkan pendapatan keluarga petani yang bersangkutan. Pemerintah ju'ga perlu menetapkan kepastian harga jual benih padi bersertifikat/bermutu, agar dapat memberi rangsangan kepada petani untuk menjadi penangkar benih padi unggul dan kebutuhan benih daerah.

Upaya pemenuhan kebutuhan benih di masing-masing wilayah/desa perlu ditumbuhkembangkan secara mandiri oleh kelompok tani, kelompok penangkar, atau gabungan 
kelompok tani dengan kelompok penangkar untuk memproduksi benih. Kegiatan desa mandiri benih merupakan bentuk kebijakan Kementrian Pertanian untuk tujuan pemenuhan benih secara mandiri. Kebijakan ini merupakan implementasi Program Kerja Presiden RI yang tertuang dalam RPJMN 2015-2019. Kegiatan Desa Mandiri Benih merupakan salah satu kegiatan yang diharapkan dapat mendukung pencapaian sasaran produksi dan merupakan salah satu upaya pemecahan masalah dari aspek perbenihan (Dirjen Tanaman Pangan, 2016). Tujuan penelitian ini untuk menganilisis resiko penangkar benih padi di Kabupaten Pringsewu.

\section{Metode}

Penelitian dilaksanakan di Kabupaten Pringsewu. Lokasi ditentukan secara sengaja (purposive), dengan pertimbangan bahwa Kabupaten Pringsewu merupakan sentra penghasil padi di Provinsi Lampung. Berdasarkan perhitungan, sampel penelitian terdiri dari 37 petani penangkar padi dan 37 petani nonpenangkar padi. Pengumpulan data penelitian ini dilakukan pada bulan November 2017.

Penelitian ini membutuhkan metode koefisien variasi untuk menganalisis risiko. Koefisien variasi $(\mathrm{CV})$ merupakan ukuran risiko relatif yang diperoleh dengan membagi standar deviasi dengan nilai yang diharapkan (Pappas dan Hirschey, 1995). Jika nilai koefisien variasi (CV) diketahui, maka kita akan dapat mengetahui besarnya risiko yang harus ditanggung petani dalam usahatani padi. Nilai CV berbanding lurus dengan risiko yang dihadapi petani padi, artinya semakin besar nilai $\mathrm{CV}$ yang didapat maka semakin besar pula risiko yang harus ditanggung petani. Begitu pula sebaliknya, semakin rendah nilai CV yang diperoleh maka risiko yang harus ditanggung petani akan semakin kecil.

Pengukuran risiko secara statistik, dilakukan dengan menggunakan ukuran ragam (variance) dan simpangan baku (standard deviation). Pengukuran ragam dan simpangan baku digunakan untuk mengetahui besarnya penyimpangan pada pengamatan sebenarnya di sekitar nilai rata-rata yang diharapkan. Ukuran untuk hasil yang diharapkan adalah hasil rata-rata (mean) (Kadarsan, 1995), pengukuran dirumuskan sebagai berikut:

\section{Error! Reference source not}

found.

Keterangan $: \bar{\pi} \quad=$ keuntungan rata-rata $(\mathrm{Rp})$

$\pi \mathrm{i} \quad=$ keuntungan yang diterima petani $(\mathrm{Rp})$

$\mathrm{n} \quad=$ jumlah musim yang diteliti (empat musim)

Perhitungan ragam (variance) menggunakan rumus (Supranto, 2000):

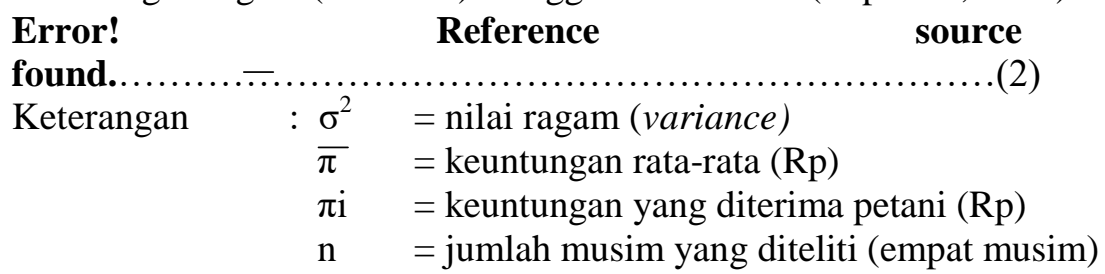

not

Perhitungan simpangan baku (standard deviation) menggunakan rumus (Supranto, 2000):

Error! Reference source not

found.

Keterangan $: \sigma^{2} \quad=$ nilai ragam (variance)

$\sigma \quad=$ simpangan baku (standar deviasi)

Besarnya keuntungan yang diharapkan menggambarkan jumlah rata-rata keuntungan yang diperoleh petani, sedangkan simpangan baku $(\sigma)$ merupakan besarnya fluktuasi keuntungan yang mungkin diperoleh atau merupakan risiko yang ditanggung petani. Untuk melihat nilai risiko dalam memberikan suatu hasil dapat dipakai ukuran keuntungan koefisien variasi dengan rumus sebagai berikut (Pappas dan Hirschey, 1995): 
Error! Reference source not

found.

Keterangan $: \bar{\pi} \quad=$ keuntungan rata-rata $(\mathrm{Rp})$

$\sigma \quad=$ simpangan baku (standar deviasi)

$\mathrm{CV}=$ koefisien variasi

\section{Hasil dan Pembahasan}

\section{Gambaran Umum Petani Responden}

Berdasarkan hasil penelitian diperoleh data bahwa petani responden termuda memiliki umur 31 tahun dan petani responden tertua memiliki umur 69 tahun. Menurut Mantra (2004), sebaran umur berdasarkan produktivitas secara ekonomi dapat dibagi menjadi tiga klasifikasi, yaitu kelompok umur $0-14$ tahun merupakan kelompok umur belum produktif, kelompok umur 15 - 64 tahun merupakan kelompok umur produktif, dan kelompok umur di atas 65 tahun merupakan kelompok umur tidak lagi produktif.

Petani responden sebagian besar berjenis kelamin laki - laki dengan persentase 100.00 persen. Hal ini disebabkan karena aktifitas dalam mengelola usahatani diperlukan tenaga yang cukup besar. Oleh karena itu, petani responden lebih besar berjenis kelamin laki - laki dibandingkan dengan perempuan.

Tingkat pendidikan formal sebagian besar adalah tamat SMP sebanyak 27 orang dengan persentase sebesar 36.49 persen. Hal ini menunjukkan bahwa tingkat pendidikan pada petani responden sudah cukup untuk menerima inovasi dalam mengelola usahataninya.

Pekerjaan sampingan yang dimiliki petani responden yaitu berdagang, buruh, honorer, dan PNS. Sebagian besar tidak memiliki pekerjaan sampingan sebanyak 33 orang dengan persentase sebesar 44,59 persen. Hal ini menunjukkan bahwa petani responden hanya bergantung kepada penghasilan usahataninya.

Pengalaman petani responden dalam berusahatani di daerah penelitian cukup beragam, yaitu pengalaman terendah adalah 5 tahun dan paling tertinggi adalah 46 tahun. Sebagian besar memiliki pengalaman berusahatani antara 5-18 tahun sebanyak 64 orang dengan persentase sebesar 86.49 persen. Hal ini menunjukkan petani responden sudah cukup berpengalaman dalam mengelola usahataninya dan diharapkan dapat mampu terus berusahatani dengan lebik baik.

Jumlah tanggungan petani responden terbanyak antara $1-3$ orang sebanyak 65 orang dengan persentase sebesar 87.84 persen. Hal ini menunjukkan jumlah tanggungan pada petani responden masih termasuk kedalam kategori sedang.

\section{Risiko Usahatani Padi}

Risiko usahatani dapat dihitung dengan melihat data produksi dan harga pada musim tanam sebelumnya. Pada penelitian ini, produksi dan harga menggunakan data musim tanam terakhir.

Koefisien variasi (CV) merupakan ukuran risiko relatif yang diperoleh dengan membagi standar deviasi dengan nilai yang diharapkan (Pappas dan Hirschey, 1995). Jika nilai koefisien variasi $(\mathrm{CV})$ diketahui, maka kita akan dapat mengetahui besarnya risiko yang harus ditanggung petani dalam usahatani padi. Nilai CV berbanding lurus dengan risiko yang dihadapi petani padi, artinya semakin besar nilai CV yang didapat maka semakin besar pula risiko yang harus ditanggung petani.

Begitu pula sebaliknya, semakin rendah nilai CV yang diperoleh maka risiko yang harus ditanggung petani akan semakin kecil. Nilai koefisien variasi pada petani penangkar benih dan nonpenangkar benih dapat dilihat pada Tabel 1.

Tabel 1. Nilai koefisien variasi (CV) pada pendapatan usahatani padi di Kabupaten Pringsewu, Tahun 2017 


\begin{tabular}{lc}
\hline Petani & koefisien variasi (CV) \\
\hline Penangkar Benih Padi & 0,348 \\
Nonpenangkar Benih Padi & 0,572 \\
\hline
\end{tabular}

Sumber : Data primer, 2017 (data diolah)

Berdasarkan Tabel 1 dapat dilihat bahwa nilai koefisien variasi (CV) pada petani penangkar benih padi lebih kecil dibandingkan petani non penangkar benih padi. Artinya usahatani padi pada petani non penangkar benih memiliki risiko yang lebih tinggi dibandingkan dengan petani penangkar benih. Hal ini disebabkan karena nilai CV berbanding lurus dengan risiko yang dihadapi petani.

\section{Simpulan dan Saran}

Tingkat risiko usahatani padi di Kabupaten Pringsewu pada petani non penangkar benih padi lebih tinggi dibandingkan dengan petani penangkar benih padi. Saran bagi petani, diharapkan dapat dimulai untuk mencoba melakukan program penangkaran benih padi, sehingga dapat meningkatkan pendapatan. Bagi pihak pemerintah, diharapkan dapat terus mendukung program penangkaran benih, baik dari bantuan modal dan sarana produksi. Bagi peneliti lain, diharapkan dapat mengevaluasi lebih lanjut perihal program penangkaran benih padi, terutama dari sisi efisiensi produksi.

\section{Daftar Pustaka}

Badan Pusat Statistik. 2016. Produktivitas Padi Sawah. Badan Pusat Statistik Provinsi Lampung. Lampung

Dinas Pertanian dan Kehutanan Kabupaten Pringsewu. 2017. Jumlah Kebutuhan dan Ketersediaan Benih. Dinas Pertanian dan Kehutanan Kabupaten Pringsewu. Pringsewu.

Dinas Pertanian dan Kehutanan Kabupaten Pringsewu. 2017. Jumlah Kebutuhan dan Ketersediaan Benih. Dinas Pertanian dan Kehutanan Kabupaten Pringsewu. Pringsewu.

Dinas Pertanian dan Kehutanan Kabupaten Pringsewu. 2017. Jumlah Petani Penangkar Benih, Produksi Benih, dan Produksi Benih Kabupaten Pringsewu per Kecamatan yang mengikuti Program Desa Mandiri Benih musim 201.. Dinas Pertanian dan Kehutanan Kabupaten Pringsewu. Pringsewu.

Dinas Pertanian dan Kehutanan Kabupaten Pringsewu. 2017. Jumlah Kebutuhan dan Ketersediaan Benih Produksi GKG, luas lahan, dan produktifitas padi di Kabupaten Pringsewu per Kecamatan yang mengikuti Program Desa Mandiri Benih. Dinas Pertanian dan Kehutanan Kabupaten Pringsewu. Pringsewu.

Direktorat Jendral Tanaman Pangan. 2016. Program Desa Mandiri Benih. Kementerian Pertanian Republik Indonesia. Jakarta.

Gujarati, D.N. 2006. Dasar - dasar Ekonometrika. Erlangga. Jakarta

Keputusan Menteri Pertanian Republik Indonesia. 2016. Pedoman Teknis Penguatan Desa Mandiri Benih Musim Anggaran 2016. Kementerian Pertanian Republik Indonesia. Jakarta.

Hendrik. 2011. Analisis Pendapatan dan Tingkat Kesejahteraan Masyarakat Nelayan Danau Pulau Besar dan Danau Bawah di Kecamatan Prdayun Kabupaten Siak Provinsi Riau. Jurnal Perikanan dan Kelautan. Vol 16 No 1. Universitas Riau. Riau

Hernanto, F. 1994. Ilmu Usahatani. Penebar Swadaya. Jakarta.

Iqbal, M. A., Lestari, D.A.H., Soelaiman, A. 2014. Analisis Pendapatan dan Kesejahteraan Rumah Tangga Petani Ubi Kayu di Kecamatan Sukadana Kabupaten Lampung Timur.Jurnal Ilmu-Ilmu Agribisnis. Vol 2 No 3

Lumintang, F.M., 2013. Pendapatan Petani Padi di Desa Teep Kecamatan Langowan Timur. Jurnal EMBA. Vol 1 No 3 (991-998).

JoFSA Vol. 1, No. 2, Oktober 2017 : 38-42 
Martiani, D., Lestari, D.A.H., Murniati, K. 2016. Tingkat Partisipasi, Struktur Pendapatan, dan Kesejahteraan Anggota Koperasi Tani Surya Sekawan di Desa Banyuwangi Kecamatan Banyumas Kabupaten Pringsewu. Jurnal Ilmu-Ilmu Agribisnis. Vol 4 No 2 (186-191).

Mosher, AT. 1987. Menciptakan Struktur Pedesaan Progresif. Yasaguna. Jakarta.

Mubyarto. 1989. Pengantar Ekonomi Pertanian. LP3ES. Jakarta

Novahadi, R., Muani, A., Imelda. 2014. Analisis Tingkat Kesejahteraan Keluarga Petani Kebun Plasma Kelapa Sawit PT. Prakarsa Tani Sejati. Tesis. Universitas Tanjungpura. Pontianak.

Pappas, J.M dan M. Hirschey. 1995. Ekonomi Managerial. Edisi Keenam Jilid II. Binarupa Aksara. Bandung.

Purba, R., Rifai, A., Kausar. 2015. Analisis Kesejahteraan Rumah Tangga Petani Plasma Kelapa Sawit Di Desa Rimbah Jaya Tran 500 Kecamatan Pagaran Tapah Darussalam Kabupaten Rokan Hulu. Tesis. Universitas Riau. Pekanbaru.

Putri, TL. DAH. Lestari, dan A. Nugraha. 2013. Pendapatan dan Kesejahteraan Petani Padi Organik Peserta Sekolah Lapangan Pengelolaan Tanaman (Sl-PTT) di Kecamatan Pagelaran Kabupaten Pringsewu. Jurnal Ilmu - Ilmu Agribisnis Vol. 1 No. 03. Universitas Lampung. Bandar Lampung. 